\title{
Conclusions: Philology as Politics, Philology as Science
}

In southern India around $1100 \mathrm{CE}$, certain unknown authors, participating in conventions that were already many centuries old, began to produce Sanskrit texts claiming to be the teachings of various divinities and other supernatural beings. The legatees of existing textual corpora that had been composed outside the region, many of these new works were the outcome of textual practices that were fundamentally philological in nature. They synthesized extant textual materials, interpreted and adapted them in light of their authors' particular interests and projects, and offered rationalized schemes of textual organization that included themselves, their textual precursors, and the scriptures of other traditions. A great many of these texts, both those cast in the narrative form of the purānas and in the prescriptive mode of the tantras, were invested in an effort to organize knowledge as it pertained to the region's Śaiva and Vaiṣnava temples, among the most significant social institutions of the far South, whose economic and political as well as religious significance surged in this period.

This anonymous philology in turn provoked changes in the intellectual habits of authors who chose to disseminate works under their own names. In Śāradātanaya's long verse essay on Sanskrit dramatic theory, a first-order adaptation of the new philology is apparent: the meandering verse-style of the anonymous philologists supplied a model for his writing, while the habit of confected citation and of the integration of already existing text into a new context supplied crucial elements of the dramaturge's modus operandi. By the time of Venkkatanātha and Maheśvarānanda, both writing around the turn of the fourteenth century, these new philologies had become long established parts of the textual universe of the far south, and their works thus provide an especially rich opportunity to assess the changes that this engendered. Venkatanātha defended the bibliographic scheme of the Pañcarātra scriptural canon, while fending off efforts of his fellow Vaiṣnavas to practice an athetizing higher criticism on parts of this canon. His purpose was thus explicitly conservative; yet his defense of his religion's scriptures evinces a new precision of both textual method and manner of argument, evidently deriving from his study of the tantras themselves. Venkațanātha's novel relationship to his scriptural sources seems to have had wider repercussions in his oeuvre, complexly interacting with his own remarkable poetic writings. And if Venkațanātha worked to con-

(C) WHITNEY COX, 2017 | DOI: 10.1163/9789004332331_007

This is an open access article distributed under the terms of the Creative Commons 
servatively defend the Pañcarātra's extant corpus of tantras, Maheśvarānanda sought to crash the gates of the Śaiva canon, and to participate in its proliferation with his own hybrid work of scholarship, belles-lettres, ritual, and theology. The Mahārthamañjari offers a testament to the epistemic openness that the new textuality seems thus to have fostered, providing a uniquely valuable reflection on the hermeneutic consequences of such openness. For Maheśvarānanda, his imagined ideal readers and he himself were at once aesthetes and religious virtuosi, the consequences of which he demonstrated at length in his culminating over-coding of the Bhagavadgit $\overline{\text { a }}$.

Although some might hopefully find the works surveyed here to be interesting in their own right, it may fairly be asked whether their study, much less their juxtaposition, tells us anything about the world that is worth knowing. A few initial responses to this immediately suggest themselves. Saaradātanaya projected the doctrines of literary theorists onto spurious works, seemingly of his own invention; Venkkațanātha was led to admit, through reason and empirical evidence, that certain works of his canon were the creation of human beings; Maheśvarānanda cheerfully accepted as much in his own work as an author. We may thus presume an awareness on all of their part of the real human agency behind the creation of their scriptural literature. Yet they surely were sincere in their understanding of these works as the transcription of a divine intention into time and history. From the point of view of hermeneutical charity, we might attempt to inhabit this thought-world, with its porous and overlapping notions of who is authorized to speak in the voice of a god.

And as in the case of other modes of textual scholarship before the coming of modernity, we may also admiringly note the sheer human effort involved in this scholarly labor. The physical and mental exertion required to procure and to work through such an enormous quantity of text-artifacts - as anyone who has ever worked with palmleaf manuscripts in the Grantha script can attest, they are resolutely not a user-friendly medium - the pains taken in memorization, composition, revision, and public dissemination: all of this summons up a world of practices that we moderns can scarcely imagine. Venkkațanātha, who was impossibly prolific in Sanskrit, Tamil and Manipravālam, provides a limit case here. Seeing a real problem at work in the varied claims to revelation, and gaining a new appreciation that the philology of medieval India was worthwhile because it was hard: these might be valuable in their own right, but neither is enough.

If we take our admiration for our scholarly forebears as only a starting point, what might we learn from these modes of philology? First of all, there is the fact that a history of them can even be written. I hope to have demonstrated that it is not only possible, but also a productive way to approach even well- 
known works and authors. But the significance of this small contribution to a nascent history of global philology may perhaps be best brought out by setting it within a more capacious context, and within an explicitly comparative frame of reference. I conclude by offering two such attempts: first, by linking these scholarly projects to the wider political and institutional domains in which they took shape; second, by seeing them as assimilable to the historical study of the rational techniques for understanding the human and natural world, that is, of science.

\section{Context One: Philology in and as Temple-State Politics}

All three of our philologists were close contemporaries, were Brahman men who were the recipients of a traditional saastric education and poetic training, and were inheritors of broadly similar corpora of scriptural literature. Śāradātanaya, as far as we can tell, might have spent his whole life in the learned otium of an agrahära, a Brahmanical estate: there is little that can be said of his environment, other than it was broadly representative of the brahmanical culture from which the purāṇas and tantras emerged. Ven̉kațanātha and Maheśvarānanda were active in similar milieux, the great temple-cities of Śrirangam and Cidambaram. Venkkațanātha had been born and raised near Kāñcī, in the north of the Tamil country, and in traditional accounts he is said to have had a highly mobile career, including supposed periods of exile fleeing the armies of the Delhi sultan; ${ }^{1}$ Maheśvarānanda for his part boasts of his wanderlust. ${ }^{2}$ But both spent their productive years in these great Śaiva and Vaiṣnava centers: Maheśvara writes explicitly of composing the Mahärthamañjarı̄ while resident in Cidambaram; whether or not Venkațanātha lived in Śrīrangam at the time of the Pãñcarätrarakșā's composition, its arguments were intended for the community centered there, the hub of the southern Vaiṣnava world of his day.

1 See Hopkins, Singing the body of God, $5^{8-75}$ for a succinct synthesis of the existing narrative accounts of Venkațanātha's life; the only evidence of the historical Venkațanātha's awareness of Muslims derives from a passing reference in his Abhïtistava (vs. 22ab: kalipraṇidhilakșaṇaih kalitaśākyalokāyataị̣ turuṣkayavanādibhirjagatijrmbhamānạm bhayam, "[Oh Lord, destroy] the fear that grows great in the world through the Turks and Arabs, those agents of the Kali age who have urged on the Buddhists and the materialists."). That Venkațanātha sees the threat of Islam to lie in the realm of philosophical doxography does not lend much credence to the idea that he had first-hand experience of the armies of the Sultanate.

2 Speaking of his early life, he writes: "He passed the time wandering to the ends of the earth." (Mañjarī, 190: paryațaṃś ca diśām antān kālaṃ kañcid avāhayat). 
By the turn of the fourteenth century, these two centres were sprawling Brahmanical city-states, each the apex of complex agrarian order. The final decline of the imperial Cola kings left in its wake what were in essence small, wealthy autonomous polities centered on the two temple complexes, the ruling societies of which maintained alliances with the shifting constellations of kings, pretenders, and local strongmen that made up the ruling élite of post-Cola times. Consider the campaign led by Jațāvarman Sundara Pāṇdya: in $1258 \mathrm{CE}$, this king from the far south left a welter of grandiloquent inscriptions on the walls of both temple complexes, memorializing the occasion of spectacular ritual actions. ${ }^{3}$ The two temple-cities were thus sites of record for the royal politics of our authors' time, and supplied the stages for public performance with consequences well beyond their own precincts. ${ }^{4}$

The sources for a social history of these massively important institutions are many and ready to hand: I reviewed earlier the beginnings of the Brahmanical hegemony centered on Cidambaram (see pp. 4off, above); by the end of the thirteenth century, this group had aggrandized into a substantial landholding class throughout the micro-region, and had been joined by an increasingly powerful network of matams or monasteries drawing their membership and support from the dominant agrarian gentry. ${ }^{5}$ The Śrīrangam temple

3 Cidambaram: see South Indian Inscriptions vol. 4 (Mysore: Archaelogical Survey of India, 1986-), nos. 618-621, 624-632; Śrīrangam, South Indian Inscriptons vol. 24, nos. 194-199. Interestingly, these clusters of inscriptions are markedly different in flavor: the Śrïrangam records, predominantly in Sanskrit verse, record Sundara Pāṇdya's extensive donations to the temple; those in Cidambaram, largely in poetic Tamil, are martial and erotic in their subject matter, mentioning in passing the Pāṇdya king's performance of a tuläbhāra ceremony (where the king gives away his weight in gold: 4:620, in Tamil prose).

4 Compare Emmanuel Francis and Charlotte Schmid, "Preface," in Pondicherry Inscriptions, Vol. 2, ed. G. Vijayavenugopal (Pondichéry: Institut Français de Pondichéry/École Française d'Extrême-Orient, 2010), xxi ff., who theorize the existence of Cola-era 'meykkirtti sites' as places of particular élite political-rhetorical investment; on the notion of the epigraphic 'stage,' see Noboru Karashima, “South Indian Temple Inscriptions: a New Approach To Their Study," South Asia:Journal of South Asian Studies 19, no. 1 (1996): 1-12.

5 In addition to the fourth volume of South Indian Inscriptions, which contains part (though by no means all) of the Cidambaram epigraphic corpus, significant secondary studies of the medieval temple-city include S.R. Subrahmanyam, "The Oldest Chidambaram Inscriptions (Part 2)," Journal of Annamalai University 13 (1942): 55-91; Kenneth R. Hall, "Merchants, Rulers, and Priests in an Early South Indian Sacred Centre: Cidambaram in the Age of the Cōlas," in Structure and Society in Early South India. Essays in Honour of Noboru Karashima, ed. Kenneth R. Hall (Delhi: Oxford University Press, 2001); Orr, "Temple Life at Chidambaram;" B.G.L. Swamy, Chidambaram and Națarāja: Problems and Rationalization (Mysore: Geetha 
complex possessed, like Cidambaram, an enormous epigraphical archive, and was the subject of an internally diffuse and heterogeneous narrative text (the Koyilŏluku, a work that awaits reassessment by current scholarship), while providing the scene for a considerable body of Sanskrit and Tamil early-modern hagiography. ${ }^{6}$

The Cola state system had provided these two sites with more than just their material wealth; as suggested earlier, the enormous growth of the regional temple culture supplied a powerful impetus to the creation of the tantra and purāṇa literature that preceded Venkațanātha and Maheśvarānanda's own work. It was these works that provided these new and newly-empowered sites with liturgies, narratives of origin, and a place in the wider fabric of pan-Indic culture. And so it was in these great temple-states where the stakes of Saiva and Vaiṣnava philology were particularly high. In the case of Śrīrangam, there is some evidence to suggest that the politics of scriptural philology impinged directly on the wider life of the institution. The temple authorities there may have changed the liturgy from the Pañcarātrins to that of the Vaikhānasas under the influence of Orissan occupiers in the years 1223-1225, a few decades before the active lifetime of our authors. ${ }^{7}$

Book House, 1979); and Paul Younger, The home of dancing Śivan: the traditions of the Hindu temple in Citamparam (New York: Oxford University Press, 1995), esp. 125-158: the last two should be read with caution. Herman Kulke, Cidambaramāhātmya: eine Untersuchung der religions- geschichtlichen und historischen Hintergründe für die Entstehung der Tradition einer südindischen Tempelstadt (Wiesbaden: Harrassowitz, 1970); David Smith, The Dance of Siva: religion, art and poetry in South India (Cambridge: Cambridge University Press, 1996); and Karen Prentiss, The embodiment of bhakti (New York: Oxford University Press, 1999) all contain much useful information, although their principal interest is not the social history of the temple. See also Cox, Politics, Kingship and Poetry, 176-200, for a longer account of the transformations of Cidambaram in this period.

6 Other than the pioneering work of edition and interpretation by V.N. Hari Rao (Köil Olugu: the chronicle of the Srirangam temple with historical notes (Madras: Rochouse, 1961); History of the Srïrangam Temple (Tirupati: Sri Venkateswara University, 1976)), the Koyilŏluku provides one of the key sources to Appadurai's ethnohistorical study (Worship and conflict under colonial rule: a South Indian case (Cambridge: Cambridge University Press 1981), 85-101); the social history of Śrīrangam's epigraphy (published in SII 24, with useful notes and a learned introduction) is capably surveyed in Leslie Orr, "The Vaiṣnava community at Śrīrangam: the testimony of early medieval inscriptions," Journal of Vaiṣnava Studies 3, no. 3 (1995): 109-136. Venkațanātha's place in the hagiographic literature is surveyed in Hopkins, Singing the body of God.

7 Leach "The Three Jewels," following Rastelli, Die Tradition des Pāñcarātra im Spiegel der Pārameśvarasaṃhitā (Vienna: Verlag der Österreichischen Akademie der Wissenschaften, 2006) (who in turn bases herself on Hari Rao, History of the Srirangam Temple) states this 
Venkațanātha's efforts at rapprochement between the two Vaiṣnava orders (pp. 10off, above) might thus have possessed a powerful and very this-worldly impetus. This is only a single example of Venkațanātha's supposed public commitments: Vaiṣnava hagiographical accounts connect him with the efforts to spirit away the Rangganāthasvāmin idol from Śrīranggam when the temple-city was sacked by the armies of Malik Kafur (ca. 1310), as they assign to his hand a laudatory inscriptional verse in honor of Gopanārya, the Vijayanagara brahman 'general' responsible for the subsequent reestablishment of the temple's main image. ${ }^{8}$ Whatever the historical truth of these accounts, they are united in

as historical fact; the evidence for this, however, is far more equivocal. Evidence for the presence of Orissans at the Śrīrangam temple is furnished by an inscription dated to 28 February $1225 \mathrm{CE}$ in the ninth regnal year of Māravarman Sundara Pāṇdya (twice published in South Indian Inscriptions: 4:500 and 24:192), recording a decision (vyavasthai, ll. 1, 14) re-organizing the election of temple officials from the ranks of the Śrīvaiṣnava liturgical elite. This new arrangement was put into place owing to the earlier actions of ten unnamed temple officials who, during their tenures of office, 'had colluded with the Oḍas' and committed a lengthy list of financial malfeasances, leading to the disruption of worship and the impoverishment of the temple endowment (ll. 5-6, 9: munnāạlil koyilukku nirvvāhakarāy patinamu ceytu pattupperumāka avaravar kālattu oțtaroțe kūṭi niñru [...] ippați tiruvārātanan tațtup-

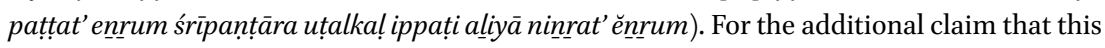
disruption resulted in adoption of Vaikhānasa ritual practice, we must turn to the Koyilōluku, which describes how in the aftermath of an invasion from Orissa "some of the servants in the temple became traitors to Śrïrangam, and even some priests fell in with this group, and perverting the truth, fled. Some Vaișnava brahmans, being learned in the blessed Vaikhānasa śästra, began to perform temple worship. Followers of other religious orders, those who are practitioners of the six systems of thought, then freely set up homes and began to live in the sacred territory of the Śrīrangam." (Koyilŏluku, 35: sthalattile cila parijanankal rangadrohikalāy atil arccakarum anupravișțarāy mĕy tīyntu pokaiyil, śrīvaikhānasaśāstrajñarānana nampimār ārādhanam paṇnikkŏnțtu vantavarkal. itaramatastharāna șațsamayattārum tiruvarañkantirupatiyile vītu kaț̣ikkŏṇțu svatantramāy iruntārkal.) As Hari Rao (History of the Śrirangam Temple, 70) notes, this account is retrojected into the tenth century, "during the pontificate of Uyyakoṇ̣ār and Maṇakkāl Nampi." This positivist blunder on the Koyilŏluku's compilers' part, however, may contain a significant detail, for the text goes on to attribute to this situation Yāmuna's 'conversion' to the Śrīvaiṣnava path by Maṇakkāl Nampi, and his subsequent composition of the Ágamaprämänyam in order to refute the new nonVaiṣnava colonists in Śrīrangam (History of the Śrïrangam Temple, Hari Rao misunderstands this passage in his translation (39), and thus fails to notice this literary-historical detail). The Koyilŏluku's account may thus contain a reflex of the philological tensions at work in Venkațanātha's text, projected back in time onto Yāmuna, in a manner consistent with the Pāñcarātrarakșā's own invocations of the earlier work.

8 See the discussion by Eugen Hultzsch in Epigraphia Indica, vol. 6, 322-330, who notes the 
their presentation of Venkațanātha's efforts to preserve the Vaiṣnava ordersomething to which his later recruitment as the founding figure of the vatakalai ('northern tendency') sectarian tradition also attests. ${ }^{9}$ Certainly Venkatanātha was involved in the institutional Vaiṣnavism of Śrīrangam and Kãñcipuram, and there were surely political, as well as theological, stakes to this involvement.

In contrast to Venkkaṭanātha's status as a Vaiṣnava celebrity, Maheśvarānanda cut no public figure. The Mahārthamañjari was to be widely copied and periodically cited and admired, but its author-none of whose other works surviveevidently avoided any entanglement with the complex world of Cidambaram in the wake of the Cola period, or at least he left no surviving trace of such involvement. The construction around 1250 of a temple consecrated to Kālī, Maheśvarānanda's iștadevatā, under the auspices of the Kāțava warlord Kopperuñcinkan might have been of some significance in the tāntrika's life, but I know of nothing linking him to it. ${ }^{10}$ Nor do we have any clear sense of what the changes underway in the Śaiva temple-city might have meant for him: while Cidambaram knew no major disruptions to its worship, it was seemingly in this period that it adopted its peculiar position in the landscape of Tamil temples, as the privately held property of an interrelated group of priestly families, the Dīkṣitars. Whether Maheśvarānanda was a distant ancestor of the temple's modern proprietors, or whether he lived as a rentier in one of Cidambaram's surrounding pițākai-suburbs - there is not a trace of evidence to allow us to decide this. He was almost certainly a witness to a remarkably fertile time and place for Śaiva scholarship. Cidambaram in the thirteenth and fourteenth century was the site for a host of different visions of the Śaiva religion, whether cast in Sanskrit or Tamil-among them the many different works in both languages attributed to Umāpatiśivācārya and the other major works of the Tamil Śaivasiddhānta (the Měykaṇtaccāttirañkal), and the peculiar Śivādvaita espoused in Srìkanțha's commentary on the Brahmasūtras. Again, however, there is no trace of these works to be found in the Mahārthamañjarí.

appearance of this verse in the Guruparamparāprabhāva (where it is attributed to Venkkatanātha) and the Koyilŏluku (where it is not).

9 See Raman, Self-Surrender (Prapatti), 4-14, 156-172 on this attribution and its anachronistic lack of fit to the thought of the historical Venkațanātha, see also Hardy ("The Philosopher As Poet," 309-318) on the patterns of theological reason that can be abstracted from one of Veñkațanātha's stava-hymns.

10 The foundation is dateable on the basis of an unpublished inscription (Annual Report of South Indian Epigraphy, no. 401 of 1903); on Kopperuñcinkan see Nilakantha Sastri, The Cōlas, 422 ff. and especially Es. Ar. Pālacuppiramaṇiyam, Peṇu centamil vālap piranta Kāțavan Kōpperuñcinkan (Cennnai: Pāri Nilaiyam, 1965). 
However paradoxically, the lack of any notice of Maheśvarānanda outside his own work signals an extraordinary political fact of late-medieval philology: its independence. Neither Maheśvarānanda nor Veñkațanātha seems to have had any involvement with royal patronage or court politics: whatever his prominence within the Vaișnava world of his day, the hagiographical efforts to link Venkațanātha with the Vijayanagara dynasty are unconvincing, to my eyes at least. Maheśvarānanda, if anything, appears to have had the more typical career: a learned man of the agrahāra, he was able to produce his work of radical scholarship secure in the fact that it could reach an audience of readers who could appreciate his wide reading and enjoy the boldness of his conception. Despite his acts of textualized self-deification and his maverick recasting of the Gitta, his work, in contrast to his philological contemporaries in the Latinate, Perso-Arabic or Sinitic worlds, excited no public denunciations, required no licensure for its publication, and - for all its overwhelming linguistic exuberance-did not need to be obscured by allegory or coded expression. Imagine Menocchio without an Inquisition.

Maheśvarānanda's work as a Śaiva philologist seems to have been premised on just this sort of autonomy; it is not going too far to see his insistent focus upon svātantryam and naiścintyam-independence and fearless self-confidence-as a soteriological gloss on this, an abstraction grounded in the real conditions of his social existence. Faced with this, it is best to demur from Pollock's insistence on the strictly courtly location of philological scholarship in premodern India. When he writes that "all the critical innovations in the aestheticization of language and its philologization came from the stimulus offered by court patronage," Pollock is grounded in an extraordinary survey of Indic literary history, as well as in a powerful critique of the inherited thinking about the instrumental relationship of culture to power. ${ }^{11}$ Nevertheless, there are strong reasons to doubt this supposed centrality. The immensity of the extant corpus of Indic manuscripts did not come about as a result of massively funded and efficient royal scriptoria, but by the time and effort of unknown private copyists. This suggests that the work of composition as well as reproduction took place in ways that were distributed and decentralized. The anonymous philologists traced here were by no means indifferent to courtly or royal attention-kings, as well as being possible open-handed patrons, were eminently good to think with - but the work of scholarship and authorship carried on far away from the centers of high politics.

11 Pollock, The Language of the Gods, 523; on the critique of legitimation theory and other examples of social-scientific reductionism, see Pollock, The Language of the Gods, 511-524. 
Pollock's compelling effort to rethink the culture-power connection in premodern India in fact inadvertently reproduces a long-standing historiographical problem, the insistent focus on the dynastic state as the unit of historical relevance. This has allowed him to teach us extraordinary things, for instance about the competition between political formations that was an engine for much innovative literary and theoretical writing. ${ }^{12}$ But an unintended consequence of this way of organizing the data tends to misrecognize those times and places - like the far South in the thirteenth and fourteenth centuries - that fall between the cracks of dynastically construed history. These become unstructured terrain: the central Kāveri plain between the Cola and Vijayanagara hegemonies was thus the scene of Hoysala, Pāndya, and Khalji martial incursions, but little else. ${ }^{13}$ The philology of this time and place suggests something much different, above all an intellectual and concomitantly social dynamism that our available historiographic tools do little to help us to capture. It is perhaps by starting with what we can know about this admittedly élite form of culture and sociality that we may prove able to frame research questions that can prompt a different, and fundamentally better, understanding of this past world.

\section{Context Two: Indic Philology and the History of Science}

It is not at all original to suggest that the history of philology can be profitably seen as a part of the history of science; outside of southern Asia-where the history of textual scholarship is, as we have seen, underdeveloped - this is already standard practice. For instance, in the field of classical and Renaissance studies, Grafton's several surveys of Kepler's dual career as Latinist and astronomer, and his intellectual biography of the astrologer Girolamo Cardano demonstrate the inseparability of philological methods from wider modes of rational inquiry; ${ }^{14}$ while Sebastiano Timpanaro's classic historical analysis of

12 On royal patronage as a spur to the sciences of language ('grammar envy'), see Pollock, The Language of the Gods, 177-188; on the inter-court competition around the turn of the second millennium that produced the several brilliant generations of Kannada poets and critics (Pampa, Ranna, Nāgavarma), see Pollock, The Language of the Gods, 356-363, 368374 .

13 The lack of a synthetic historical scholarship on this period since Krishnaswami Aiyangar's sophisticated but exclusively political-historical South India and her Muhammadan Invaders (London: H. Milford, Oxford University Press, 1921[!]) supplies an eloquent demonstration of this problem.

For Kepler, see Anthony Grafton, Defenders of the Text: The Traditions of Scholarship in 
Lachmannian editing - in its close attention to the development of the isolable elements of a methodological program - is itself a model history of scientific technique. ${ }^{15}$ Beyond the limits of the western Eurasian subcontinent, Benjamin Elman's work on the K'ao-cheng scholarship of the late Ming dynasty explicitly takes its bearings from an explicitly Kuhnian framework of conceptual and institutional change. ${ }^{16}$ And very recently, there has appeared a manifesto of sorts for an alliance between the history of science and the history of textual scholarship. Lorraine Daston and Glenn Most begin from the shared institutional and intellectual space occupied by astronomy and Classical philology in the nineteenth century German research university, but they proceed to argue for something much more ambitious: a genuinely comparative, transregional history of philology, focusing above all on the practices, rather than the objects, of a range of philologies, as a prolegomenon to a more general comparative enterprise of the history of knowledge and of systematic rational endeavour uniting the natural and the human sciences. ${ }^{17}$

For all of this earlier thinking on the subject, it might be objected that the materials studied earlier - from the poet Cekkilāar's manipulation of the documentary order to Maheśvarānanda's self-reflexive overcoding of the norms of commentarial scholarship - might be too eccentric from any systematic norm of textual scholarship to be understood as analogous to scientific rationality. Moreover, historical science studies is a large, complex, and contentious field, and I do not claim anything remotely approaching a comprehensive view of it. But even a brief review of some of it suggests there is much that a historian of Indian philology can learn from this scholarship, both to usefully question

An Age of Science, 1450-1800 (Cambridge: Harvard University Press, 1991) 178-203; and Worlds Made by Words: Scholarship and Community in the Modern West (Cambridge: Harvard University Press, 2009), 114-136; for Cardano, see Grafton, Cardano's Cosmos: The Worlds and Works of a Renaissance Astrologer (Cambridge: Harvard University Press, 1999), especially $127^{-155}$.

15 Sebastiano Timpanaro, The Genesis of Lachmann's Method, trans. Glen R. Most (Chicago: University of Chicago Press, 2005); Most, in his commendable introduction to his translation, examines the book as an instance of the history of science (Timpanaro, The Genesis of Lachmann's Method, 18-25).

16 Benjamin Elman, From Philosophy to Philology: Social and Intellectual Aspects of Change in Late Imperial China (Cambridge: Harvard University Council on East Asian Studies, 1990), e.g. 88-137; cf. the appreciation of this work in Pollock, "Future Philology?" 944.

17 Lorraine Daston and Glenn W. Most, "History of Science and History of Philologies" Isis 106, no. 2 (2015): 378-39o. This superb, if brief and programmatic, essay only came to my attention during the final revisions of the present study. 
conventional wisdom and to provoke future lines of inquiry. ${ }^{18}$ I propose three such lessons here: the insistence upon a historicism that refuses in advance to subordinate its scholarly object to another set of contemporaneous causes or processes; the commitment to avoiding a teleological view of historical change; and an attention to the technical details of the practice of knowledge-making, and a corresponding willingness to admit into explanation the agency of nonrational, even insentient entities.

\section{Non-Reductive Historicism}

In situating Veṅkațanātha, Maheśvarānanda, and their anonymous forebears within the institutional worlds of Śrīrangam and Cidambaram, I do not wish to claim that their scholarship should be seen to be epiphenomenal to the politics of these local worlds, or to the wider politics of the post-Cola South. Surely-as I suggested above-knowledge of this institutional setting raises important questions, and gives some intimation of the wider stakes of their arguments. But attention to however much or little we may know of the circumambient world of politics and social power cannot exhaust our inquiry into the world of textual studies in medieval (or other) times; nor can it meaningfully explain the innovations of method or of argument that these contained. When Venkațanātha repurposed the scriptural category of sankara, 'contamination,' and the need for its avoidance into a broadly conceived method of textual study, he was not simply advancing the claim of his particular liturgical rite to dominance, however much his methods may have subserved such a claim, or however much he himself may have sought such an outcome. ${ }^{19}$ But

18 Without laying any claim to how representative these works may be of their wider discipline(s), I have found several works to be especially useful. Peter Galison, "Ten Problems in History and Philosophy of Science." Isis 99 no. 1 (2008): 111-124 (a state-of-the-discipline overview) and Bruno Latour's widely-cited study (Science in action: how to follow scientists and engineers through society (Cambridge: Harvard University Press, 1987)) both supply useful methodological frameworks. As practical exempla of the field, see Steven Shapin and Simon Schaffer's deservedly classic case-study (Leviathan and the Air-pump: Hobbes, Boyle, and the Experimental Life (Princeton: Princeton University Press, 1985); see also Steven Shapin, "The house of experiment in seventeenth-century England," Isis 79, no. 3 (1988): 373-404; and the responses to the book in Ian Hacking, "Artificial Phenomena," The British Journal for the History of Science 24 no. 2 (1991): 235-241; and Bruno Latour, We have never been modern (Cambridge: Harvard University Press, 1993), esp. 13-48), and Mario Biagioli, Galileo, Courtier: the Practice of Science in the Culture of Absolutism (Chicago: University of Chicago Press, 1993) and idem, Galileo's Instruments of Credit: Telescopes, Images, Secrecy (Chicago: University of Chicago Press 2006).

This is plausibly suggested by Leach, "The Three Jewels." 
neither could Galileo Galilei's decision to name the first four moons of Jupiter visible to his newly invented telescope after members of the Medici family of Florence warrant the reduction of the optics of his apparatus or the history of observational astronomy to the political vagaries of seventeenth century Florence. ${ }^{20}$ For all that a history of Indic philology needs to avoid the caricature of the idealised, otherworldly domain of the premodern pandit - with his eyes set solely on the promise of mokșa - so too it must be wary of a too-easy collapse of complex social institutions and self-aware intellectual practices into the undifferentiated workings of the field of power.

This is hardly a problem unique to the study of past science, though the debates there on non-reductive historicization, or what is more technically termed the 'internalism-externalism debate', have been especially trenchant. ${ }^{21}$ For early South India, our uneven access to adequate evidence for social history has encouraged a habit of premature reduction to external motivation wherever possible: a scrap of historical information - a dedicatory verse to a ruling king, for example-warrants the reading of a complex work as solely epiphenomenal to the legitimation of a certain royal house. The new southern scriptural philology and its sāastric inheritors suggest that a more capacious view of a brutely 'external' context needs to be admitted. In the first instance, we need to account empirically for the diversity of institutional forums in which textual scholarship was practiced, in order that then - and only thenit may become possible to venture inferences about the wider collective or individual projects in which these practices were imbricated. It is only in so far as we can recognize the remove at which Maheśvarānanda operated from the public life of Cidambaram in contrast to Venkațanātha that we can begin to frame hypotheses about these two men, the cities in which they spent their working lives, and the religious orders that flourished in these cities.

\section{The Refusal of Teleology}

The anti-teleological understanding of conceptual and practical change is central to contemporary science studies: Kuhn's classic model of competing paradigms and the periodic crises of research agenda, which supplies the basso continuo for much of the field, relies on exactly this premise. The responses

20 See Biagioli, Galileo, Courtier, 127-139.

21 See especially Galison "Ten problems" (whose label "non-reductive contextualization" I adapt here) and Steven Shapin, "Discipline and bounding: The history and sociology of science as seen through the externalism-internalism debate," History of Science 30 (1992): $333-369$. 
to, demurs from, and critiques of Kuhn are practically a field unto themselves, one in which I claim no special authority. And his model has bequeathed to the English language - for good and ill — the now-tired figure of the 'paradigm shift'. Amidst all of this, the basic fact of Kuhn's argument is often forgotten. Scientific knowledge is not, the argument goes, the result of the steady accumulation of truth and the sifting out of error, but the ongoing outcome of conflicts between two or more incommensurable ways of approaching a problem, the formulation of one of which cannot necessarily appeal to an external standard (aside from "the assent of the relevant community") to disprove the other. It follows from this that the appearance of an unproblematic continuity within a given field over a long period of time is an artifact of the system-internal workings of a given paradigm, of 'normal science' to use Kuhn's jargon. That is, any such continuities are what the problems addressed by previously overcome paradigms look like from within the horizon of a subsequent regime of education and research, rhetorically committed to its own capacity to exhaust the phenomena under discussion. Thus Newtonian dynamics can be taken, in Kuhn's example, to be a special instance of relativistic dynamics only through a spurious 'derivation' of the former from the latter. ${ }^{22}$

I think that the value of this for cross-cultural comparison is obvious. In the face of such a theory, we would commit a serious methodological error were we to simply recruit Venkkatanātha — with his sense of textual history and his principled aversion to the editor's scalpel—into a Whiggish history of evolving text-critical and philological technique. ${ }^{23}$ In doing this, we might in good conscience class Śāradātanaya (a magpie and a forger) and Maheśvarānanda (an eccentric, possibly a lunatic) as suitable objects of philological study, but not surely as philologists themselves.

Even if we avoid this kind of overly simple teleology, is it legitimate to regard Veñkațanātha's work as more rigorous or more successful than Śāradātanaya's or Maheśvarānanda's? Can we understand the Vaiṣnava's work to provide a basis for comparison with the philology of other times and places more readily than the Śaiva's hermeneutical eccentricities, or the religiously eclec-

22 On the forensic model of securing assent within a research community, see Thomas Kuhn, The Structure of Scientific Revolutions (Chicago: University of Chicago Press, 1996), 94ff.; on the relationship between the Newtonian and the relativistic models, see 101103.

23 This is roughly the epistemological stance seen in such earlier (and, it need to be emphasized, very learned and useful) attempts at the history of philological techniques in Sanskrit, such as Colas, "Critique et Transmission;" Gode, "Textual Criticism," and Bhattacharya, "Use of Manuscripts." 
tic dramaturge's compositional sleights of hand? More strongly, given the differences between all these men's work, can we even account for their different modes of philology within a single conceptual frame? Or is one philology, another mendacity, and the other just perversely inventive interpretation?

Taking these works in a single gaze enables us to reformulate such comparative questions, while avoiding their teleological pitfalls. All three situated themselves within similar textual fields, for all that the details of their particular ontologies and soteriologies differed. All three works evince, as I have argued, a response to the techniques available to their anonymous predecessors, and for all of them the instability of the landscape of anonymous Sanskrit literature provided the occasion for composition; all were composed in a complex tension with their authors' literary sensibilities and interests. Despite the differences of matter and authorial style, the textual projects embodied in the Bhāvaprakāśana, the Pāñcarātrarakșā and the Mahārthamañjarī were basically of a piece, differential responses to parallel historical stimuli.

But while these very different works are intelligible within a common historical and conceptual framework, we need to attend to another, less obvious, shared feature: none of them seems to have inaugurated a larger shift in the practices, textual or otherwise, of their disciplines. Kuhn's model is less helpful in coming to terms with this second kind of implicit teleology, as the logic of his argument forces him to rely on the notion of 'anticipations' of eventual crises, smuggling in a latent figurative structure into his otherwise admirably contingent view of conceptual change. From the perspective of such Kuhnian anticipation, these three men writing around the turn of the fourteenth century possessed an awareness of the epistemic gap provoked by the proliferation of works of revelation, but they could be said to have "made no contact with a recognized trouble spot" in the textual practices of their time, and thus occasioned no wider transformation. ${ }^{24}$

Śāradātanaya's work, which is ironically the easiest of these texts to dismiss, came closest to meeting these conditions. The wider crisis of textual authority that expressed itself in Perāciriyar's conservatism is diagnosed, if inadevertently, by the Bhāvaprakāśana's textual habits, and Śāradātanaya's work was to remain an authority to readers for centuries. Were we to adopt this thread of Kuhn's model and apply it to our temple-state philologists, we would be led to ask what exactly it was that failed to catch fire in Maheśvarānanda and Venkațanātha's own context, and in what circumstances did the ensuing crisis 
of textual knowledge, if any, take place? The luxuriant scriptural proliferation of this period led to what seems from this distance to be an eventual exhaustion of the exclusivist soteriologies of the Śaivas and the Vaisnavas: the temple culture which the tantras helped to sustain broadened out beyond the ambit of these texts, as can be seen in the eventual success of more vernacular modes of worship and sociality, and a wider concern with social recognition and the apportionment of honors than was the case in our philologists' era. ${ }^{25}$ The liturgies of the temples all the way down to modern times continued to be drawn from the tantric corpora, but these ceased to be a major focus of élite intellectual concern. Increasingly, this concern shifted to the trans-sectarian idiom of Vedānta, to which Venkkațanātha (that is, Vedāntadeśika) of course made profound contributions.

Yet the kind of scholarship practiced here does not seem to have simply represented an intellectual dead end: far from it. It is possible-to continue with this tentative admission of the intimation of later crises- to see these philologist-śāstrīs as precursors of that self-consciously 'new' scholarship of early modern times which has been the subject of much recent and productive scholarly attention. ${ }^{26}$ To be certain, the proponents of navya learning did not engage in a large-scale way with purānic or tantric textual criticism, though their own problems brought them into contact (and conflict) with the authoritative statements of the author-compilers of the purānas especially. ${ }^{27}$ More

25 On the early-modern concern with temple honors, see Appadurai and Breckenridge's classic study (Arjun Appadurai and Carol Appadurai Breckenridge, "The South Indian Temple: Authority, Honour, and Redistribution," Contributions to Indian Sociology 10, no. 2 (1976): 187-211). Based on ethnographic fieldwork, their model does not make any claims about periodization; I propose that much of its focus upon the redistribution of honors (Ta. mariyātai) and shares (Ta. pankku) pertains to early-modern times. I base this on my impressionistic sense of medieval temple epigraphy, where I have not encountered these terms as major areas of concern. For corroborating evidence of this, see the Tamilk kalvẹttuc cŏllakaräti, pp. 381 (some slight references to pañku), and 481 (notably no reference at all for mariyātai; the cognate mariyāti is glossed as 'valakkam' or 'custom,' based on a single reference).

26 Much of this has been conducted under the auspices of the Sanskrit Knowledge Systems on the Eve of Colonialism project (http://www.columbia.edu/itc/mealac/pollock/sks/), for a survey of which see Sheldon Pollock, ed., Forms of Knowledge in Early Modern Asia: Explorations in the Intellectual History of India and Tibet, 1500-180o (Durham, NC: Duke University Press, 2011).

27 For instance, see Christopher Minkowski, "Astronomers and Their Reasons: Working Paper on Jyotihśāstra," Journal of Indian Philosophy 30 no. 2 (2002): 495-514 on the encounters between astral science (jyotiḩśāstra) and purānic cosmographies. 
broadly, the ad fontes attitude which characterized much of this work across a variety of fields could be portrayed as a further reaction to the proliferation of authoritative textual knowledge with which our authors, in their different ways, were involved.

Of potentially great significance here is the work of Appayya Dỉkșita (ca. 1520-1593). The connections between Dìkșita and these authors are many: he was the commentator on Veñkațanātha's largest Sanskrit poetic work; he was an advocate of the late-medieval Śivādvaita of Śrikkanțha who occasioned claims of spurious textual fabrication; a scholar whose Kuvalayānanda, on literary tropology, relied on techniques of textual borrowing and recasting familiar to the old anonymous philology; and a Śaiva theorist who was potentially familiar with the Mahärthamañjarī. ${ }^{28}$ For a better picture of these connections, we will have to await the much-needed intellectual biography of Appayya; ${ }^{29}$ nevertheless, it is possible to intelligibly frame Venkkațanātha and Maheśvarānanda's efforts in such a forward-looking, prefigurative manner.

Such a synthesizing project could prove productive, supplying a useful bridgehead between the increasingly independent historiographies of medieval and early modern India. Still, it would be a mistake to too-hastily assimilate Maheśvarānanda's intellectual world with Appayya's, as many as eight generations later. Until we have more adequately mapped the conceptual, institutional, and bibliographic terrain of the understudied later medieval world, its internal coherence and long-term trajectories will remain in the realm of cautious hypothesis. The work of the anonymous Southern philologists and their śāstric inheritors may prove to be a phenomenon exemplary in precisely its isolation from later scholarly practices and habits of thought. From this perspective, Maheśvarānanda and Ven̉kațanātha might best be seen as the most pre-

28 For this suggestion I am grateful to Jonathon Duquette, who in a personal communication has conveyed to me some evidence of verbal parallels between Maheśvarānanda and Appayya's Śivārkamanidīpikā. I await the publication of Dr. Duquette's research, which will hopefully cast important light on the relationship between the sixteenth century 'bull of the Draviḍas' and his Śaiva predecessors.

29 N. Ramesan, Sri Appayya Dikshita (Hyderabad: Srimad Appayya Dikshitendra Granthavali Prakasana Samithi, 1972) while thorough, can no longer be considered up-to-date. For now, refer to Yigal Bronner, "What Is New and What Is Navya: Sanskrit Poetics on the Eve of Colonialism," Journal of Indian Philosophy 30.5 (2002): 441-462; idem, "Back to the Future: Appayya Dīkṣita's Kuvalayānanda and the Rewriting of Sanskrit Poetics," Wiener Zeitschrift für die Kunde Südasiens 48 (2004): 47-79; and Lawrence McCrea, "Coloring Tradition: Appayyadīkșita's Invention of Śrīkanțha's Vedānta," unpublished paper, n.d. On Śrīkaṇţha's Śivādvaita, S.S. Suryanarayana Sastri, The Śivādvaita of Śrīkaṇțha (Madras: University of Madras, 1972) can still be consulted with profit. 
cociously gifted and radical participants in a long cultural moment that would not produce any successors, something worthy of study in its own right. ${ }^{30}$

\section{The Agency of the Non-Human}

The bibliographic scheme in which the Sütasamhitā placed itself seems to have exerted a profound influence on the creation of later texts assigning themselves to the Skandapurāna and on the Keralan Jaiminìyasam hitā. Cekkilār produced some of the poetic frisson of his account of Cuntaramürtti's calling through his invocation of the everyday details of the documentary practices of his day. The inventions of Śāradātanaya's dramaturgical compendium depended on the crowd of texts competing for the attention of contemporary readers; Aṭiyārkkunallār's great commentary bemoaned the loss or fragmentation of an earlier Tamil scholarly dispensation. Veñkațanātha repurposed the Vaiṣnava tantric authors' fear of textual métissage to create new canons of philological study, and his scrupulous recording of citations perhaps derived from an accessible collection of written texts, an archive. And it was perhaps the taken-for-granted details of the local realia of manuscript text-objects - the intersection of hand, eye, stylus, leaf, and lampblack — that permitted Maheśvarānanda's jarring collision of quotation and comment, source-text and interpretative gloss in his radical revision of the Bhagavadgittā. In all of these cases, we see the workingout of unintended consequences, as well as the ways in which technical and practical details can exert powerful and unanticipated effects, even when those details are seemingly trivial. And in all of these cases, human agents can be seen to be imbricated not only in the physical matrices of their textual cultures, but also in the spontaneously arising theories of textuality embedded in particulars form of literate life-ways.

Philology is sometimes accused, usually by those ignorant of its practice, of being idealist, as trafficking in imagined textual essences. That this is far from being the case can be seen from these instances, as it can from a myriad of others. What is of interest to me is less the disproving of philology (and philologists) as unworldly, than accounting for just how much the worldin all its seemingly solid pregiven thingyness-is an active contributor to the creation of this kind of knowledge. The world consists of more than just brute objects, of course: the saṃkara that so bothered the Pāñcarātrika authors was a conceptual and lexical invention, though one that possessed powerful nuances

3o For some parallel reflections on the premature collapse of the medieval into the early modern, concentrating on very different source material, see Whitney Cox, "Scribe and Script in the Cālukya West Deccan," Indian Economic and Social History Review 47 no. 1 (2010): $24 \mathrm{ff}$. 
(of impurity, of miscegenation) that would have been viscerally repugnant to an orthodox Brahman like Venkațanātha. The use of this category thus invoked a range of associations, a string of perilous parallel cases, a ramifying proliferation of ethical judgments, suggestions that Venkațanātha's adoption of it retained intact.

What might a history look like in which we treat factors such as these not as just structuring constraints but as active participants in the creation of knowledge? Can we apportion agency in such a way that we can see the informing conditions of the textual format adopted by Maheśvarānanda or his amanuensis as central to the production of his reading of the Bhagavadgit $\bar{a}$ ? Is it intelligible to think that the material, social, and ideological inflections of this particular local manuscript culture might be as significant to our interpretation as are those much-discussed effects of the print revolution elsewhere in time and space? ${ }^{31}$

Perhaps this is asking too much of poorly-understood phenomena, and is too taxing of our impoverished explanatory resources. All the same, the practical examples that fill the pages of the history of science suggest that the explanatory burden in accounts of discovery or theorization can often be shifted to insentient agents, first and foremost to those delimited and controlled sectors of nature ("experiments") whose coming-into-knowledge provides the narrative matter of such histories. To take a celebrated example: Robert Boyle's

31 There is a small library devoted to tracking the epochal transformations of the introduction of moveable-type print, of which Elizabeth Eisenstein, The Printing Press as an Agent of Change: Communications and Cultural Transformations in Early-Modern Europe (New York: Cambridge University Press, 1979) and Benedict R. O'G. Anderson, Imagined Communities (London: Verso, 1991) are only major touchstones. Departing from these, especially from Anderson, Sheldon Pollock, "Literary Culture and Manuscript Culture in Precolonial India," in Literary Cultures and the Material Book, ed. Simon Eliot et al (London: The British Library, 2007), 77-94 offers a comprehensive overview of South Asian manuscript culture, polemically suggesting the importance attributed to print to be exaggerated in the South Asian case. Sascha Ebeling, "Tamil or 'Incomprehensible Scribble'? The Tamil Philological Commentary (urai) in the Nineteenth Century," in Between Preservation and Recreation: Tamil Traditions of Commentary, ed. Eva Wilden (Pondicherry: Institut français d'Indologie / École française d'Extrême-Orient, 2009), 281-312; and idem, "The College of Fort St George and the Transformation of Tamil Philology during the Nineteenth Century," in The Madras School ofOrientalism:Producing Knowledge in Colonial South India, ed. Thomas R. Trautmann (Delhi: Oxford University Press, 2009), 233-26o are two detailed case studies of the intellectual and institutional consequences of the transition to print in colonial Tamilnadu, along with cogent sketches of the precolonial, manuscript-based practices of Tamil philology. 
air-pump, its manufacture by Robert Hooke and its retooling in Boyle's laboratory, its tendency to leak, and the imperfect vacuum produced within it all supplied Steven Shapin and Simon Schaffer with one of the leading agents in their description of the emergence of experimental science in Restoration England, and of the intransigent opposition to it by Thomas Hobbes and others. Shapin and Schaffer understood the machina Boyleana as only one of several technologies at play in this narrative-alongside a "literary technology" of the emergent form of scientific rapportage and a "social technology" of the professional comportment of researchers - but it was the apparatus and its capacity to produce matters of fact which lay at the center of the several overlapping discursive, material, and institutional fields for which they account. ${ }^{32}$ This suggests, at the very least, that we should be prepared to work 'backwards' from seemingly coherent, self-identical works of textualized language to the multiple forces that subtended their creation, just as Boyle's writings (or the Harvard Case History in Experimental Science through which modern students of Boyle encounter his work) can be said to establish only a portion of the relevant evidence.

If we can allow enough ontological latitude to admit non-human, nonrational agents into our history, another part of the story of the success of the philology of the tantras and puränas comes into view: the impress of the anonymous style itself. The dialogical style of verse-composition in simple Sanskrit was something pregiven - the southerners who wrote in this way had an enormous library of examples on which to base themselves, and by and large they eschewed any changes to their inherited model. Composing a conversation between, say, the great god Siva and the sage Nārada, an author had recourse to a recognizable set of formulae, to the loose-fitting constraints of the verse rhythms of the anuștubh meter, and to a permissiveness of awkward or even barbarous language, as only the gods can be allowed grammatical license within the norm-obsessed world of Sanskrit literates. ${ }^{33}$ The style was a leisurely one, with its slow eliciting of information through question and answer, the potential to speak of a point in brief or to dilate over many hundreds of couplets,

32 Shapin and Schaffer, Leviathan and the Air-pump, esp. 22-79.

33 On so-called aiśa language (the language "of God;" the name used by the Śaiva scholiast Kșemarāja to describe the register of the Svacchandatantra), see Goodall, Bhațtarāmakanthaviracitā kiranavrttih, pp. lxv-lxx; for a wider statement of this theme of the divine derangement of Sanskrit, see Charles Malamoud's elegant essay "The Gods Have No Shadows: Reflections on the Secret Language of the Gods in Ancient India," in Cooking the World: Ritual and thought in Ancient India, trans. David G. White (Delhi: Oxford University Press, 1996), 195-206. 
to dive headlong into theological intricacy or to mark time while stringing along narrative and poetic commonplaces. This can try the patience of even the most sympathetic modern reader, but it exerted a powerful effect on the texts' initial and intended readers-for all that it lacks in elegance, purānic and tantric language possesses (as was evidently meant to possess) a certain aura, a mantle of authority.

This authority granted to the purānic and tantric style gave its users a great deal of compositional freedom, permitting the author-compilers of the Sütasam hitā, for instance, to rove at will over the whole of Brahmanical literature. Nor was its use a purely strategic effort at self-legitimation: rather the style, ready to hand and always-already there, had a tendency to overwhelm its individual composers, to speak through them. This is one reason why these works tend to bulk so large: texts like the Sütasaṃhitä's long and diffuse Yajñavaibhavakhanda at times resemble exercises in versified automatic writing. Where do we place the locus of authorial agency in cases like this: in the anonymous compilers, their sources, the norms of the inherited literary form, or in some hybrid intersection of all of these?

If we are thus willing to admit that a history of old Indic philology might best be prepared to supplement an account of exclusively human-centered agency with a more capacious framework, then yet another set of entities present themselves for inclusion: the gods. Simple hermeneutical charity suggests this; as we have seen, it was a live possibility in this world to condemn as spurious work claiming for itself the status of divine revelation-Venkațanātha did so to his opponents and his fellow Vaiṣnavas alike. But these condemnations took shape against a background of works composed, copied, preserved, and expounded by men, which those men claimed to be the ipsissima verba of a host of divine figures. From our perspective, it is easy to see this all as an act of enormous bad faith, if not a centuries-long conspiracy. That this is inadequate is obvious. All the same, I for one would prefer to keep my humanism, materialism, and historicism intact. What to do?

Though cast in a form that resists easy summation, and in a manner that is typically idiosyncratic, Bruno Latour's exercises towards a 'symmetrical anthropology' of religion are of some use here. ${ }^{34}$ Departing from his earlier work in the sociology of science and the tacit theory of modernity, Latour's argument amounts to a social-scientific nondualism. The sundering of subject from object that is definitive of 'modern,' 'critical' thought (the extension of these terms is somewhat vague) has produced in Latour's account a series of mutually 
interpenetrating conundrums, among them the invention of 'belief' as a mental state possessed by other people ('the Blacks,' in Latour's arch but unhappy term), the concomitant positing of a cognitive and moral freedom possessed by the moderns ('the Whites', ditto); the condemnation of fabricated things to which are ascribed independent powers as 'fetishes', and the parallel fetishization of the supposedly independent, value-neutral 'facts' of scientific knowledge, thought of as pregiven by nature and unfabricated, etymology and science studies be damned. To work towards collapsing these dichotomies, Latour produces a portmanteau - 'factish'-meant to suggest the binding up of subjective awareness and objective actuality, of construction and efficacy within a given chunk of the universe, for which he offers as examples Pasteur's lactic acid bath and a shaligram (properly śălagrāma, a Vaiṣnava emblem usually containing an ammonite fossil ${ }^{35}$ ). As entities entangled in networks of actors and practices, the set of Latour's factishes include divinities, whether the gods of a Candomble initiate or the apparition of the Virgin Mary at Lourdes. He is emphatic that this is not just a case of 'representation'-any more than are the matters of fact produced in laboratory science - but opportunities to see the collection of overlapping agencies found in the world from a different, and more adequate, perspective.

All of this admittedly is rather wooly, but Latour's willingness to accept what he calls "the variable-geometry ontologies" of nonhuman entities has its attractions. Latour's entangled actors resemble nothing so much as Maheśvarānanda's view of the person as the contingent intersection of circuits of feminized divinities and phenomenological potentialities, though the comparison might seem detrimental to one or both men. ${ }^{36}$ At the very least, the symmetries Latour proposes supply us with an ethnohistorical injunction to perform the difficult work of trying to inhabit the multiply-entangled world of our medieval philologists, whatever their metaphysical commitments. All of these philologists - and here they are exemplary of the wider world of Sanskrit and vernacular literates - understood the world to be shot through with the tropes and topoi of the universe of discourse in which they spent much of their imaginative and intellectual lives. It was through works of language that

35 Latour draws this example from U.R. Anantha Murthy's novel Bharathipura (On the modern cult, $25 \mathrm{ff}$.); he does not seem to be aware of the paleontological significance of this common piece of ritual accoutrement, though I imagine it might be of interest.

36 Latour, On the modern cult p. 43; on Maheśvarānanda's theory of the person, see Cox "A South Indian Śākta Anthropogony," and compare the similar (and wonderfully evocative) description of the imaginative practice in the Saundaryalahari in Shulman, More than Real, 120-134. 
they experienced the world at its most real; it was the eye that fell on the text that for them most clearly saw the nature of things. But the continuum of subject, object, human, and divine that Latour sees as incompletely sundered in modernity was not available to our medieval south India philological virtuosi in some prelapsarian, sub-Heideggerian purity. Instead, its tensions and disjunctions were plotted for them within the boundaries of this textually saturated mode of consciousness. They, and their works, were as entangled within these as Latour's experimental apparatus or contemporary religious vision.

\section{Problems and Prospects}

I began by presenting the conceptual and lexical problem that attends the study of premodern philological practice in South Asia: for all that methodical and virtuoso readers undeniably existed, there exists no identifiable emic label which would permit us to infer a critical and practical self-consciousness on their part. This nominalist concession was framed by a suggestion, that intensified modes of reading were perhaps so bound up in the fabric of intellectual life that they literally went without saying. And there is certainly abundant evidence that the making and the understanding of texts was a widely disseminated élite activity, one that grew more pervasive and more intense with the beginning of the second millennium of the common era. Although it has gone all but unaddressed here, this increase can be correlated with the vernacular transformation of these same centuries: the self-aware philological armature of Cekkilāā's Pěriyapurānam and Aṭiyārkkunallār's effort to exhaustively document the lost world of the Cilappatikäram are both suggestive of the wider amplitude of vernacular textual creation and interpretation. ${ }^{37}$

A comprehensive historical survey of these practices remains a task for the future, a scholarly desideratum that must necessarily be the work of many hands. I will conclude by offering a few recapitulations as to the shape such a history might take, using Ven̉kațanātha and Maheśvarānanda's works as a point of departure. As both men's relationship to their textual antecedents and to their own philological methods suggests, the horizon of intelligibility of textual scholarship depends in the first instance on the scholar's own account, whether tacit or explicit, of his methods. While this should really be a truism of historical reconstruction - seeing things from the other chap's point of viewI find there to be surprisingly little sympathy for this, at least within Indology.

This is, of course, a major theme of Pollock, The Language of the Gods. 
Positive knowledge can be gathered from works of premodern philology whose presumptions differ as radically from our own as Maheśvarānanda's, yet positivism alone cannot help us to answer, or to even frame, the questions that a work like his can raise. The relationship between such hermeneutically charitable reconstruction and modern critical scholarship is not one of dichotomy, as it is often thought by both sides to the argument. Instead, it is an ideally virtuous circle. Speaking purely anecdotally, it was my own effort to understand the tacit logic of the Mahārthamañjarı that occasioned my attempt to partly edit the work; the process of edition not only sharpened my sense of its linguistic fabric, but raised altogether new questions about Maheśvara's deeply self-conscious understanding of the act of text-making.

The history of philology can easily fall into one of two broad types, each legitimate and intellectually significant in and of themselves: on the one hand, a history of practices, seeking to produce a narrative of the evolving body of methods and doctrines by which a given textual field was interpreted and explained; on the other, a history of philology's imbrication in wider social and intellectual frameworks. Both of these styles of inquiry, however, turn upon a shared problematic which - in a final recourse to Latourian nondualism-we may call the reconstruction of the social universe of past modes of scholarship.

Both Veñkațanātha and Maheśvarānanda are exemplary in how, in very different ways, their works serve to collapse this dichotomy: the Pāñcarātrarakșä's attempt to purge both the social and textual domains of samkara starkly illustrates how closely the technical and socio-political domains of philology were bound together for Venkkațanātha. Contrariwise, Maheśvarānanda's deliberate fusion of yogin and sahrdaya in imagining the sociality of the Mahārthamañjari-an emergent social microverse in which the author deliberately set himself as his readers' equal—takes on an almost poignant quality. On the one hand, the Śaiva author's marginal place in the institutional world of his time demonstrates that political-courtly preferment and innovative scholarly production need not necessarily be linked. Communities of scholarly authors and readers could be quite literally imagined into existence, free from social and political constraints, and even from the material constraints that print culture would eventually bring to bear on South Asian learning. Maheśvarānanda had no patron, royal or otherwise, because he did not need one; among the literate élites of his time and place creating a text required only the will to do so and the leisure to see it through to completion. The Mahärthamañjari's many manuscript witnesses descend to us through the labors of one copyist at a time, men who found the text deserving of their own will and leisure to read and to reproduce. But the figure of the hermeneutical yogin takes on a different quality when we consider how poorly the work as an 
integral, authorially sanctioned product fared outside of its own local textualcultural ecology: in distant Kashmir — the land of the most ideal of Maheśvarānanda's ideal readers - some scribe or scribes saw fit to cut the Mañjari down in a way that undid its author's unique vision of a readerly, philologically driven salvation.

What all of this suggests to me is that an attempt to historically reconstruct past habits of philology necessitates both hermeneutic charity and the most rigorous pursuit of the discipline of context. The work of a truly symmetrical, genuinely historical history of global philology is still in its infancy, if not its gestation. Such a history will only succeed insofar as it proves itself willing to traverse textual and intellectual terrain that is very different from the cluster of local textual ecologies that saw the emergence of the critical philological methods of the early modern and modern West. But this inquiry can only yield results if the imaginal, linguistically grounded worlds of its historical subjects can be understood in terms of their value within the wider social universes of their emergence. This task, and its potential intellectual payoff, are not limited to the idiographic needs of particular specialist fields, as much as specialist knowledge and methods are an absolute necessity. Any such inquiry must have in its background the question of the place of our own philological ways of life, within our own conjunctural situation, both within the institution of the university and more broadly still, as local and global citizens. Surprising though it may be, it is only working through these possibilities of what textual study has meant in the past-in terms of its acheivements, its limitations, its points of brilliant focus as well as of myopic blindness - that its possible futures might yet be imagined. 